\title{
A new record for the mite fauna of Turkey: Molothrognathus shirazicus (Acari: Caligonellidae) and the first description of its protonymph
}

\author{
Mustafa AKYOL (10 \\ Department of Biology, Faculty of Arts and Sciences, Manisa Celal Bayar University, Manisa, Turkey \\ e-mail: mustafa.akyol@cbu.edu.tr
}

Received: 1 January 2021

Accepted: 25 January 2021

Available online: 27 January 2021

\begin{abstract}
ASBTRACT: Molothrognathus shirazicus Khanjani, Bakhshi and Khanjani, 2016 is founded for the first time from Turkey and new report to the mite fauna of Turkey. The female and protonymph specimens of the species are collected from soil and litter under Pinus brutia, P. nigra, Olea europaea, Paliurus spina-christi, Pistacia terebinthus and Verbascum sp., Afyonkarahisar, Manisa, İzmir and Antalya provinces, Turkey. Also, the protonymph stage of M. shirazicus is described for the first time in this study. A key to all known species of the genus Molothrognathus of Turkey is given.
\end{abstract}

Keywords: Prostigmata, Raphignathoidea, Molothrognathus, new report, Turkey.

Zoobank: http://zoobank.org/18B9D939-0EEA-4DBB-AAC5-57E2050268BD

\section{INTRODUCTION}

Members of the family Caligonellidae (Acari: Raphignathoidea) are free-living predatory mites that feed on small arthropods and found in various habitats (Khanjani et al., 2016; Akyol, 2018; Amini et al., 2018; Doğan and Doğan, 2020), and with a world-wide distribution (Fan and Zhang, 2005). This family contains 5 genera and 67 species in the world (Doğan and Doğan, 2020). The genus Molothrognathus Summers and Schlinger belongs to the family Caligonellidae, so far contains 27 known species in the world, and is represented with 6 species in Turkey, viz. M. bahariensis Ueckermann and Khanjani, M. crucis Summers and Schlinger, M. kamili Doğan, M. phytocolus Meyer and Ueckermann, M. terrulentus Meyer and Ueckermann and M. venusta (Khaustov and Kuznetzov) (Koç and Ayylldı,, 1997; Doğan, 2003, 2019; Akyol and Koç, 2012; Doğan and Doğan, 2020). In this study, a new record of Turkish fauna Molothrognathus shirazicus Khanjani, Bakhshi and Khanjani is illustrated and described based on the adult females and protonymph.

\section{MATERIALS AND METHODS}

The specimens were collected from soil and litter under Pinus brutia, P. nigra (Pinaceae), Olea europaea (Oleaceae), Paliurus spina-christi (Rhamnaceae), Pistacia terebinthus (Anacardiaceae) and Verbascum sp. (Scrophulariaceae), in Afyonkarahisar, Manisa, İzmir and Antalya provinces, Turkey, and taken to the laboratory in plastic bags and extracted by Berlese-Tullgren funnels for 7 days. Mites were collected in $70 \%$ ethanol and mounted on slides in modified Hoyer's medium. The mite specimens were measured and drawn by means of a research microscope (Nikon Eclipse E 400). The setal nomenclature follows those of Kethley (1990) and Grandjean (1944). The drawn specimen's measurements were given first and followed by range of measurements (minimummaximum) of other specimens in parentheses. All meas- urements were given in micrometres $(\mu \mathrm{m})$. Measurements of legs were taken from base of femur to tips of tarsal claws. The specimens are deposited as slidemounted in the (CBZM), Manisa, Turkey. See Zhang (2018) for abbreviations.

\section{RESULTS}

Family: Caligonellidae Grandjean, 1944

Genus: Molothrognathus Summers and Schlinger, 1955

Type species. Molothrognathus leptostylus Summers and Schlinger, 1955

Diagnosis. Peritremes originating medially on stylophore, immediately behind the cheliceral stylet bases.

Molothrognathus shirazicus Khanjani, Bakhshi and Khanjani, 2016

Diagnosis. Dorsum with smooth shield between setae vi and $d 1$; palp-tibia with three setae; setae sce longest; tarsi $15(+1 \omega)-10(+1 \omega)-9-9$ (Khanjani et al., 2016).

Female $(\mathrm{n}=18)$ (Figure 1)

Length of body (excluding gnathosoma) 320 (315-325), width 190 (164-190).

Gnathosoma (Figs 1 A,B,G,H). Subcapitulum with two pairs of adoral setae (or1-2) and one pair of subcapitular setae $m 36$ (36-42). Stylophore conical. Tibial claw of palp about as long as palp-tarsus. Length of palp 143 (143156). Number of setae and solenidia from palp-trochanter to palp-tarsus: $0,1,1,3+1$ well-developed claw, $3+1 \omega+4$ eupathidia. Peritremes as depicted in Fig. 1H.

Dorsum of idiosoma (Fig. 1A). Dorsum with striae; 3 pairs of cupules present, ia behind posterior eye, im laterad of the setae $d$ and ip laterad of setae $f$; prodorsum with smooth shield and two pair of eyes. All dorsal setae are 


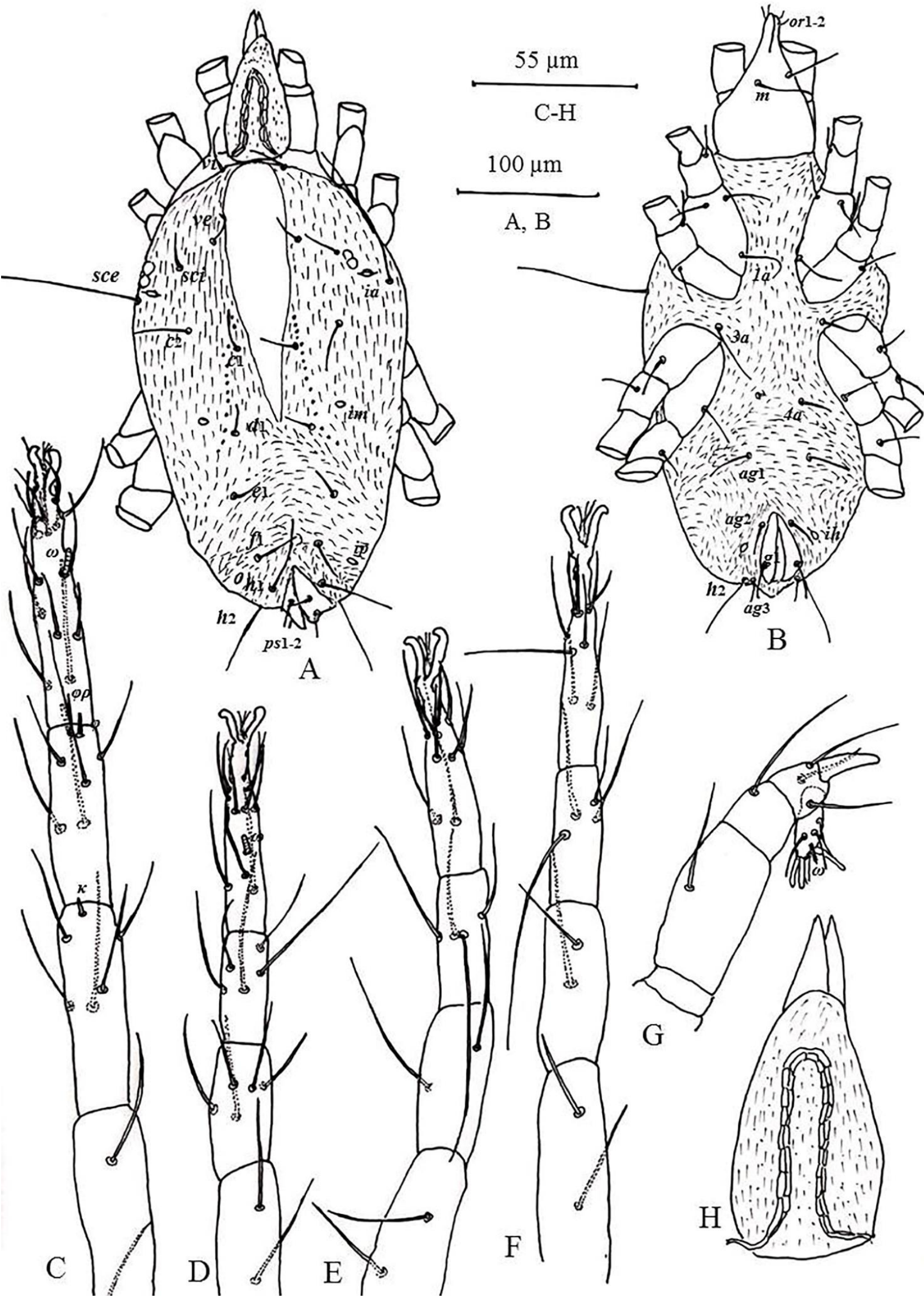

Figure 1. Molothrognathus shirazicus Khanjani, Bakhshi and Khanjani (Female) - A. Dorsal view of idiosoma, B. Ventral view of idiosoma, C. Leg I, D. Leg II, E. Leg III, F. Leg IV, G. Palp, H. Stylophore. 


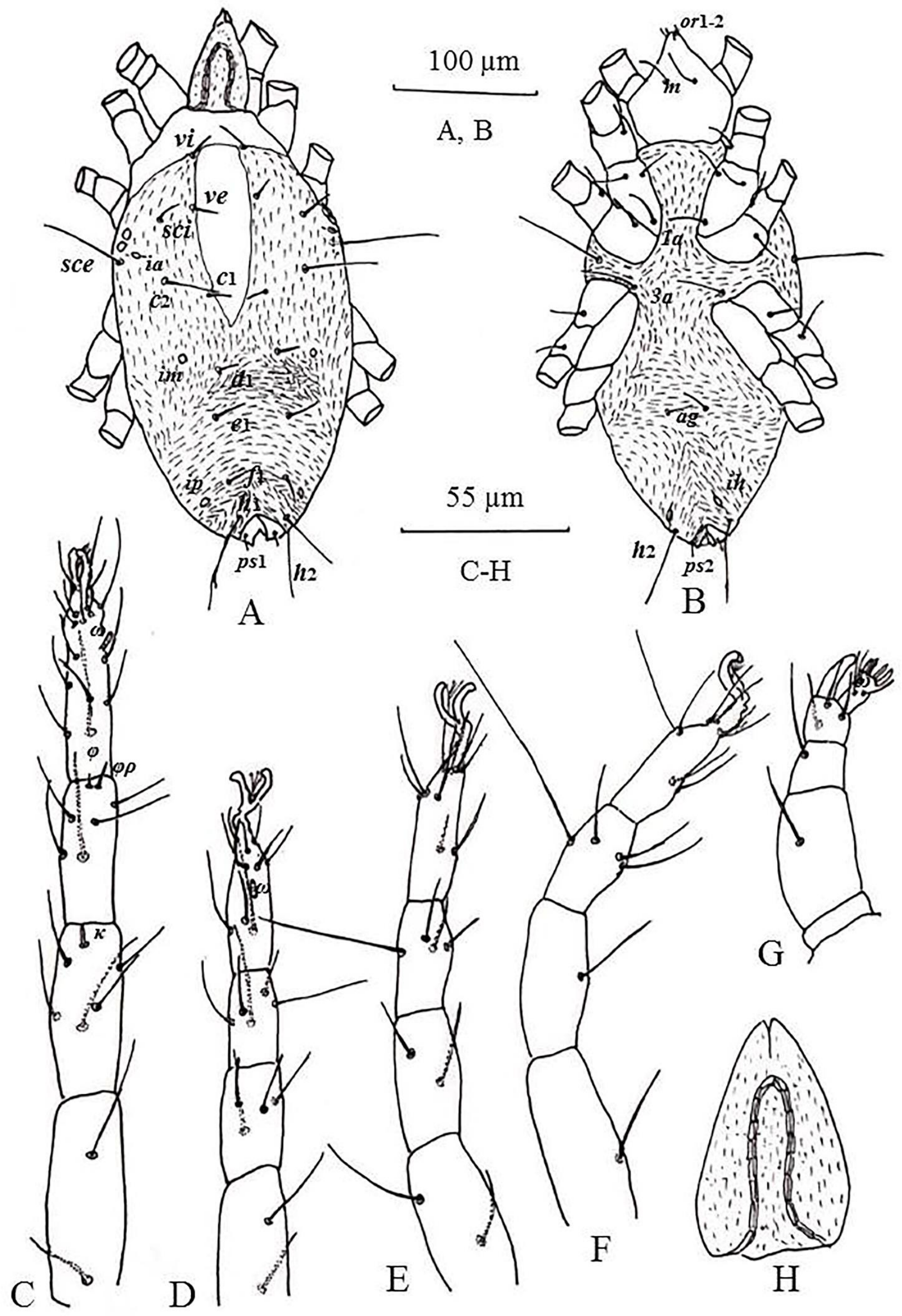

Figure 2. Molothrognathus shirazicus Khanjani, Bakhshi and Khanjani (Protonymph) - A. Dorsal view of idiosoma, B. Ventral view of idiosoma, C. Leg I, D. Leg II, E. Leg III, F. Leg IV, G. Palp, H. Stylophore. 
simple. Length of dorsal setae: vi 26 (21-26), ve 21 (1821), sci 21 (21), sce 78 (78-91), c1 16 (16), c2 36 (34-36), d1 16 (16), e1 32 (18-23), f1 26 (26), h1 52 (52-55), h2 49 (49-52). Distances between dorsal setae: vi-vi 44 (39-44), vi-ve 47 (47-49), ve-ve 55 (52-55), ve-sci 26 (26-29), sci-sci 107 (104-107), sci-sce 34 (31-34), sce-sce 151-172, sce-c1 70 (62-70), c2-c2 104 (96-104), c1-c1 36 (34-36), $c 1-d 1$ 52 (52), d1-d1 47 (39-47), d1-e1 47 (39-47), e1-e1 65 (52-65), e1-f1 47 (31-47), f1-f1 42 (36-42), f1-h1 26 (2326), h1-h1 29 (21-29), h2-h2 44 (36-44).

Venter of idiosoma (Fig. 1B). Ventral surface striated; endopodal shields absent; ventral setae three pairs: $1 a 36$ (31-36), $3 a 42$ (39-42) and $4 a 16$ (16-18); $1 a$ located on coxae I, but $3 a$ and $4 a$ located on integument; aggenital region with three pairs of setae, ag1 21 (21-26), ag2 16 (16-18) and ag3 8 (8-10); genital valves with one pair of setae $g 13$ (13-16); one pair of cupules (ih) located lateral to setae ag1. Anal shields posteriorly with two pairs of setae (ps1-2).

Legs (Figs 1C-F). Length of legs: I 234 (234-239), II 169 (169-174), III 198 (198-208), IV 216 (216-234). Setal formulae of leg segments I-IV (solenidia not included and in parentheses): coxae 3-1-1-1, trochanters 1-1-1-1, femora $2-2-2-2$, genua $5(+1 \kappa)-5-2-2$, tibiae $5(+1 \varphi+1 \varphi \rho)-5-4-$ 4 , tarsi $15(+1 \omega)-10(+1 \omega)-9-9$. Lengths of solenidia: I $\omega 6$ (6-8), II $\omega 5$ (5-6), І $\varphi \rho 7$ (7), І $\varphi 3$ (3-4), Ік 4 (4).

Protonymph $(\mathrm{n}=1)$ (Figure 2)

Length of body (excluding gnathosoma) 286, width 161.

Gnathosoma (Figs 2 A,B,G,H). Length of palp 112, palp chaetotaxy as in female. Subcapitulum one pair of subcapitular setae ( $m$ 39). Peritremes as depicted in Fig. $2 \mathrm{H}$.

Dorsum of idiosoma (Fig. 2A). Dorsal setae, cupules, shield area and striae similar to that of adult female. Length of dorsal setae: vi 21, ve 18, sci 21, sce 78, c1 16, c2 36, d1 16, $e 123, f 126, h 152, h 249$. Distances between dorsal setae: vi-vi 39, vi-ve 31, ve-ve 39, ve-sci 21, sci-sci 96, sci-sce 39, sce-sce 143, sce-c1 65, c2-c2 96, c1-c1 36, c1-d1 42, d1-d1 39, d1-e1 42, e1-e1 52, e1-f1 42, f1-f1 36, f1-h1 26, h1-h1 26, h2-h2 36.

Venter of idiosoma (Fig. 2B). Ventral surface striated; endopodal shields absent; $1 a 31,3 a 34$; one pair of aggenital setae ag 13; setae $4 a$, other aggenital setae, genital shields and its setae absent.

Legs (Figs 2 C-F). Length of legs: I 192, II 143, III 161, IV 174. Setal formulae of legs I-IV (solenidia not included and in parentheses): coxae 3-1-1-0, trochanters 1-1-1-0, femora 2-2-2-1, genua $5(+1 \kappa)-4-2-1$, tibiae $5(+1 \varphi+1 \varphi \rho)$ $5-4-4$, tarsi $15(+1 \omega)-10(+1 \omega)-9-8$. Lengths of solenidia: I $\omega$ 6, II $\omega$, I $\varphi \rho$ 6, I $\varphi$ 3, Ік 4 .

Male, deutonymph and larva. Unknown.

Material examined. Twelve females collected from litter and soil under the Pinus nigra, $1200 \mathrm{~m}$ a.s.l., Emirdağ mountains, B. Karabağ village, Bolvadin district, Afyonkarahisar province, 08 June 2019; one female from litter and soil under Verbascum sp., 130 m a.s.l., Salihli district, 23 June 2019, two females from litter and soil under Paliurus spina-christi, and one female from litter and soil under Olea europaea, $71 \mathrm{~m}$ a.s.l., Muradiye area, Yunusemre district, Manisa province, 27 September and 22 October 2019; two females from litter and soil under Pistacia terebinthus, $10 \mathrm{~m}$ a.s.l., Patara Beach, Kaş district, Antalya province, 12 July 2019; one protonymph from litter and soil under Pinus brutia, 110 m.a.s.l., Gümüldür- Menderes road $7 \mathrm{~km}$, Menderes district, İzmir province, 24 July 2019; Turkey, coll. M. Akyol.

\section{Remarks}

Molothrognathus shirazicus Khanjani, Bakhshi and Khanjani, 2016 was described for the first time from Iran and collected from soil under Populus euphratica (Salicaceae) and Platycladus orientalis (Cupressaceae), in Shiraz (altitude $1552 \mathrm{~m}$ a.s.l.), Fars province, Iran (Khanjani et al., 2016). In this study the samples collected from soil and litter under new host plants including Pinus brutia, $P$. nigra, Olea europaea, Paliurus spina-christi, Pistacia terebinthus and Verbascum sp. (altitude 10-1200 m a.s.l.) in Afyonkarahisar, Manisa, İzmir and Antalya provinces, Turkey.

Body size of 335 (278) long and 201 (120-136) wide in the Iranian specimens; 320 (315-325) long and 190 (164190) wide in the Turkish specimens. Body size of the Turkish specimens is almost similar to the Iranian specimens.

The Turkish specimens resemble the Iranian specimens, but some measurements of body setae ( $m 36-42,4 a 16, c 1$ $16, c 234-36, d 116$ in the Turkish specimens) are different from the type specimens ( $m$ 45-50, $4 a$ 23-28, $c 1$ 17$21, c 240-51, d 1$ 17-21 in the Iranian specimens).

Only female of M. shirazicus was found from the type locality (Iran) (Khanjani et al., 2016). This is the second report of this species and a new record for the Turkish fauna. Also, the protonymph stage of M. shirazicus is described for the first time in this study.

\section{Key to Molothrognathus species of Turkey}

1. Dorsal integument with simple striae ............................... 2 - Dorsal integument with dual striae ............ kamili Doğan

2. Prodorsum without shield medially ................................... 3

- Prodorsum with shield medially or finely striated spindle shaped shield - like area...................................................... 4 3. Setae sce and $c 2$ much longer than other dorsal setae; tarsi I-IV with $15(+1 \omega)-10(+1 \omega)-9-9$ setae

... M. bahariensis Ueckermann and Khanjani

- Almost all dorsal setae subequal; tarsi I-IV with $14(+1 \omega)-9(+1 \omega)-8-8$ setae

...M. venusta (Khaustov and Kuznetzov)

4. Prodorsum with finely striated spindle shaped shield like area ...................... M. phytocolus Meyer and Ueckermann - Prodorsum with shield medially ............................................... 5 5. Setae sce as long as $c 2$

... M. terrulentus Meyer and Ueckermann

- Setae sce and $c 2$ not equally long 
6. Setae $c 2$ shorter than $s c i$ and ve M. crucis Summers and Schlinger

- Setae $c 2$ longer than sci and ve M. shirazicus Khanjani, Bakhshi and Khanjani

\section{Statement of ethics approval}

Not applicable.

Funding

There is no fund for the present study.

\section{Conflict of interest}

No potential conflict of interest was reported by the author.

\section{REFERENCES}

Akyol, M. 2018. A new species of Caligonella Berlese (Acari, Caligonellidae) from Turkey. Systematic and Applied Acarology, 23 (12): 2339-2344. doi: $10.11158 /$ saa.23.12.6

Akyol, M. and Koç, K. 2012. A new species and two new records of the family Caligonellidae (Acari: Raphignathoidea) from Turkey. International Journal of Acarology, 38 (1): 40-45. doi: 10.1080/01647954.2011.583275

Amini, F., Khanjani, M. and Khanjani, M. 2018. A new species of the genus Molothrognathus Summers and Schlinger (Acari: Caligonellidae) from Kurdistan Province Iran. Acarologia, 58 (4): 875-880. doi: 10.24349/acarologia/20184293

Doğan, S. 2003. On Caligonellid mites from Turkey (Acari: Caligonellidae). Archives des Sciences, 56 (2): 63-77. doi: $10.5169 /$ seals-740431
Doğan, S. 2019. Raphignathoidea (Acari: Trombidiformes) of Turkey: A review of progress on the systematics, with an updated checklist. Acarological Studies, 1 (2): 129-151.

Doğan, S. and Doğan, S. 2020. A new record for the acarofauna of Turkey: Molothrognathus bahariensis Ueckermann and Khanjani (Acari: Caligonellidae). Journal of the Institute of Science and Technology, 10 (3): 1551-1558. doi: $10.21597 /$ jist.692883

Fan, Q.-H. and Zhang, Z.-Q. 2005. Raphignathoidea (Acari: Prostigmata). Fauna of New Zealand, 52: 400.

Grandjean, F. 1944. Observations sur les acariens de la famille des Stigmaeidae. Archives des Sciences physiques et naturelles, 26: 103-131. [In French]

Kethley, J. 1990. Acarina: Prostigmata (Actinedida). In: Soil biology guide. Dindal, D.L. (Ed.). John Wiley and Sons, New York, USA, 667-756.

Khanjani, M., Bakhshi, S. and Khanjani, M. 2016. Molothrognathus shirazicus, a new species of Caligonellidae (Acari: Prostigmata) from Iran. Persian Journal of Acarology, 5 (4): 291-297. doi: 10.22073/pja.v5i4.23685

Koç, K. and Ayyıldız, N. 1997. A new species of Molothrognathus Summers and Schlinger (Acari: Prostigmata: Caligonellidae) from Turkey. Acarologia, 38 (1): 47-50.

Zhang, Z.-Q. 2018. Repositories for mite and tick specimens: acronyms and their nomenclature. Systematic and Applied Acarology, 23: 2432-2446. doi: $10.11158 /$ saa.23.12.12

Edited by: Salih Doğan

Reviewed by: Three anonymous referees

Citation: Akyol, M. 2021. A new record for the mite fauna of Turkey: Molothrognathus shirazicus (Acari: Caligonellidae) and the first description of its protonymph. Acarological Studies, 3 (1): 43-47. 